\title{
Analisis Perbandingan Efisiensi Algoritma Brute Force dan Divide and Conquer dalam Proses Pengurutan Angka
}

\author{
Fenina Adline Twince Tobing ${ }^{1}$, James Ronald Tambunan ${ }^{2}$ \\ ${ }^{1}$ Program Studi Informatika, Fakultas Teknik dan Informatika, Universitas Multimedia Nusantara, \\ Tangerang, Indonesia \\ fenina.tobing@umn.ac.id \\ ${ }^{2}$ Program Studi Manajemen Informatika, AMIK Widya Loka, Medan, Indonesia \\ jamesronaldtambunan@gmail.com
}

Diterima 30 April 2020

Disetujui 17 Juni 2020

\begin{abstract}
Perbandingan algoritma dibutuhkan untuk mengetahui tingkat efisiensi suatu algoritma. Penelitian ini membandingkan efisiensi dari dua strategi algoritma sort yang sudah ada yaitu Brute Force dan Divide and Conquer. Algoritma Brute Force yang akan diuji adalah Bubble Sort dan Selection Sort. Algoritma Divide and Conquer yang akan diuji adalah Quick Sort dan Merge Sort. Cara yang dilakukan dalam penelitian ini adalah melakukan tes dengan data sebanyak 50 sampai 100.000 untuk setiap algoritma. Tes dilakukan dengan menggunakan bahasa pemrograman JavaScript. Hasil dari penelitian ini adalah algoritma Quick Sort dengan strategi Divide and Conquer memiliki efisiensi yang baik serta running time yang cepat dan algoritma Bubble Sort dengan strategi Brute Force memiliki efisiensi yang buruk serta running time yang lama.
\end{abstract}

Index Terms-Algoritma, Bubble Sort, Brute Force, Divide and Conquer, Efisiensi, Merge Sort, Quick Sort, Selection Sort

\section{PENDAHULUAN}

Algoritma merupakan hal yang penting dalam menyelesaikan sebuah permasalahan. Dibutuhkan sebuah metode yang tepat karena dapat mempengaruhi hasil yang diinginkan. Sebaik apapun algoritma, jika menghasilkan output yang salah, maka algoritma tersebut bukanlah algoritma yang baik. Sebuah algoritma yang baik adalah algoritma yang efektif, efisien, tepat sasaran dan terstruktur. Hal ini dapat diukur dari waktu eksekusi algoritma (running time) dan kebutuhan ruang memori (memory space) yang digunakan. Namun, kebutuhan waktu dan ruang dari suatu algoritma bergantung pada jumlah data (input) yang ingin diproses dan algoritma yang digunakan.

Algoritma sorting adalah salah satu alogitma dasar yang sering digunakan untuk menyelesaikan masalah pengurutan. Pengurutan data atau sorting merupakan salah satu jenis operasi penting dalam pengolahan data. Data yang sudah terurut memiliki beberapa keuntungan. Selain mempercepat waktu pencarian, dari data yang terurut dapat langsung diperoleh nilai maksimum dan nilai minimum.

Dalam penyelesaian algoritma sorting atau algoritma pengurutan, ada beberapa metode yang dapat digunakan yaitu: bubble sort, selection sort, insertion sort, merge sort, quick sort, heap sort, counting sort, radix sort, dan bucket sort [1]. Banyaknya metode yang dapat digunakan dalam algoritma pengurutan ini belum tentu merupakan hal yang baik, dikarenakan tidak semua jenis metode memiliki hasil running time yang baik.

Pada penelitian sebelumnya [2], mengenai perbandingan efisiensi strategi Brute Force dengan algoritma Bubble Sort dan strategi Divide and Conquer dengan algoritma Quick Sort, didapatkan bahwa algoritma Quick Sort lebih efektif dan efisien dalam menangani masalah pengurutan. Namun, algoritma yang menggunakan strategi Brute Force dan juga Divide and Conquer tidak hanya Bubble Sort dan Quick Sort tetapi ada juga Selection Sort yang masuk dalam strategi Brute Force dan Merge Sort yang masuk dalam strategi Divide and Conquer.

Berdasarkan hal tersebut, akan dianalisa strategi algoritma mana yang efektif dan efisien dalam menyelesaikan masalah pengurutan angka dengan menggunakan strategi algoritma Brute Force dan Divide and Conquer.

\section{LANDASAN TEORI}

\section{A. Algoritma Sorting}

Algoritma Sorting adalah kumpulan langkahlangkah dalam menyelesaikan masalah dengan suatu metode tertentu. Sorting didefinisikan sebagai proses pengurutan sejumlah data yang disusun secara acak menjadi terurut dan teratur. Pengurutan ini terbagi menjadi dua yaitu ascending dan descending. 


\section{B. Kompleksitas Algoritma}

Kompleksitas suatu algoritma merupakan ukuran seberapa banyak komputasi yang dibutuhkan algoritma tersebut untuk mendapatkan hasil yang diinginkan. Hal-hal yang mempengaruhi kompleksitas waktu [3]:

1. Jumlah masukan data untuk suatu algoritma (n).

2. Waktu yang dibutuhkan unutk menjalankan algoritma tersebut.

3. Ruang memori yang dibutuhkan untuk menjalankan algoritma.

Kompleksitas mempengaruhi performa atau kinerja dari suatu algoritma. Kompleksitas dibagi menjadi 3 jenis [4] yaitu:

- Kompleksitas kasus terburuk (worst case) dari algoritma adalah fungsi yang ditentukan oleh jumlah maksimum langkah-langkah yang diambil pada setiap instance dari ukuran $n$. Hal ini mewakili kurva melewati titik tertinggi dari setiap kolom.

- Kompleksitas kasus terbaik (best case) dari algoritma adalah fungsi yang didefinisikan oleh jumlah minimum langkah yang diambil pada setiap instance ukuran $n$. Hal ini mewakili kurva melewati titik terendah dari setiap kolom.

- Kompleksitas kasus rata-rata (average case) dari algoritma adalah fungsi yang didefinisikan oleh jumlah rata-rata langkah yang diambil pada setiap instance dari ukuran $n$.

Masing-masing jenis kompleksitas ini menunjukkan kecepatan atau waktu yang dibutuhkan algoritma untuk mengeksekusi sejumlah kode.

Ada 2 macam kompleksitas algoritma [5], yaitu kompleksitas waktu dan kompleksitas ruang. Kompleksitas waktu disimbolkan dengan $T(n)$ dan kompleksitas ruang $S(n)$. Kompleksitas waktu, $T(n)$, diukur dari jumlah tahapan komputasi yang dibutuhkan untuk menjalankkan algoritma sebagai fungsi dari ukuran masukan $n$. Komplesitas ruang, $S(n)$, diukur dari memori yang digunakan oleh struktur data yang terdapat di dalam algoritma sebagai fungsi dari ukuran masukan $n$.

\section{Kompleksitas Waktu}

Kompleksitas waktu [6] adalah konsep dalam ilmu komputer yang berkaitan dengan kuantifikasi jumlah waktu yang diambil oleh seperangkat kode atau algoritma untuk memproses atau menjalankan fungsi dari jumlah input.

Analisis kompleksitas waktu algoritma [7] adalah membandingkan waktu yang dibutuhkan algoritma dalam menyelesaikan perintah. Pada penelitian Estrada,A.H [8] menyebutkan bahwa dengan menganalisis kompleksitas waktu, dapat disimpulkan bahwa banyaknya jumlah data- $n$ berpengaruh terhadap kebutuhan waktu yang diperlukan.
Pada algoritma pengurutan terutama pada pengurutan dengan perbandingan, operasi dasarnya adalah operasi-operasi perbandingan elemen-elemen suatu larik dan operasi pertukaran elemen. Kedua hal itu dihitung terpisah karena jumlah keduanya tidaklah sama. Kompleksitas algoritma dinyatakan secara asimptotik dengan notasi big-O. Jika kompleksitas waktu untuk menjalankan suatu algoritma dinyatakan dengan $T(n)$ dan memenuhi $T(n) \leq C(f(n))$ untuk $n \geq n 0$, maka kompleksitas dapat dinyatakan dengan $T(n)=o(f(n))[9]$.

\section{Brute Force}

Brute Force adalah teknik paling sederhana untuk menyelesaikan permasalahan komputasi pada umumnya. Secara konseptual, Brute Force bekerja sebagai berikut [10]:

1. Mula-mula pattern dicocokkan pada awal teks

2. Dengan bergerak dari kiri ke kanan, bandingkan setiap karakter di dalam pattern dengan karakter yang bersesuaian di dalam teks sampai:

- Semua karakter yang dibandingkan cocok atau sama (pencarian berhasil), atau

- Dijumpai sebuah ketidakcocokan karakter (pencarian belum berhasil)

3. Bila pattern belum ditemukan kecocokannya dan teks belum habis, geser pattern satu karakter ke kanan dan ulangi langkah 2.

Algoritma yang menggunakan strategi Brute Force adalah algoritma Bubble Sort dan Selection Sort.

\section{D.1 Bubble Sort}

\section{D.2.1 Konsep Bubble Sort}

Bubble sort [11] adalah metode pengurutan yang membandingkan elemen yang sekarang dengan elemen berikunya, jika elemen sekarang > elemen berikutnya maka posisinya ditukar, kalau tidak, tidak perlu ditukar, misalnya untuk $\mathrm{n}=7$ maka akan dilakukan $(\mathrm{n}-1)=6$ tahap (mulai dari 0 sampai dengan $n-2)$.

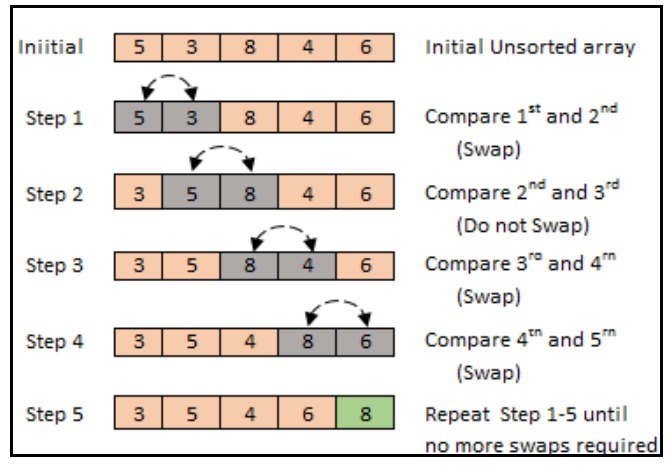

Gambar 1. Contoh simulasi bubble sort 


\section{D.2.2 Kompleksitas Bubble Sort}

Kompleksitas waktu rata-rata dari Bubble Sort adalah $O\left(n^{2}\right)$ [12]. Untuk worst case, algoritma ini memiliki kompleksitas $O\left(n^{2}\right)$ [13] saat data yang akan diurutkan diurutkan terbalik terlebih dahulu. Untuk best case, algoritma ini memiliki kompleksitas $O(n)$ [13] disaat data sudah diurutkan terlebih dahulu.

\section{D.2 Selection Sort}

\section{D.2.1 Konsep Selection Sort}

Selection Sort [11] adalah metode pengurutan yang membandingkan elemen yang sekarang dengan elemen berikutnya sampai ke elemen yang terakhir. Jika ditemukan elemen lain yang lebih kecil dari elemen sekarang maka posisinya dicatat dan langsung ditukar.

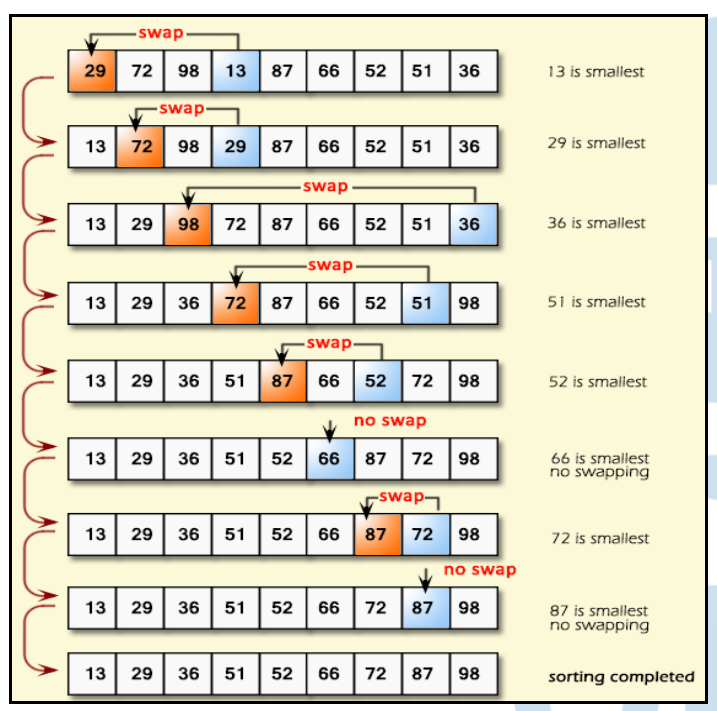

Gambar 2. Contoh simulasi selection sort

\section{D.2.2 Kompleksitas Selection Sort}

Selection Sort memiliki kompleksitas waktu ratarata, worst case, dan best case yang sama, yaitu $O\left(n^{2}\right)$ [14] dikarenakan algoritma sort ini memilki dua nested loop.

\section{E. Divide and Conquer}

Divide and Conquer adalah metode penyelesaian masalah dengan membagi masalah utama menjadi masalah yang lebih kecil. Pada strategi ini, terdapat 3 bagian utama dalam menyelesaikan suatu masalah yaitu divide, conquer, dan combine.

Algoritma yang menggunakan strategi Divide and Conquer adalah algoritma Quick Sort dan Merge Sort.

\section{E.1 Quick Sort}

\section{E.1.1 Konsep Quick Sort}

Quick Sort [15] adalah sebuah algoritma sorting dari model Divide and Conquer yaitu dengan cara mereduksi tahap demi tahap sehingga menjadi 2 bagian yang lebih kecil.

Algoritma Quick Sort melakukan sorting dengan membagi masalah menjadi sub masalah dan sub masalah dibagi lagi menjadi sub-sub masalah sehingga sorting tersebut menjadi lebih cepat walaupun memakan ruang memori yang besar.

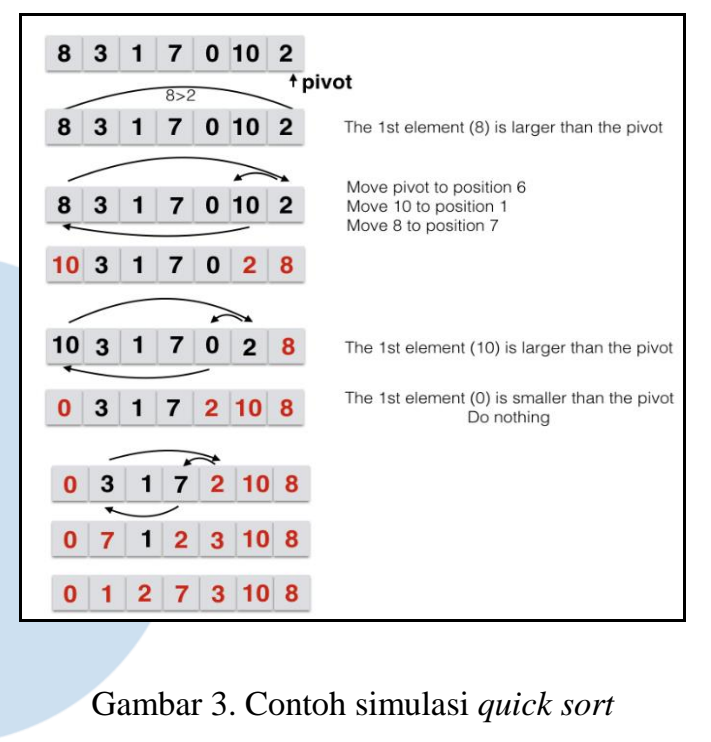

\section{E.1.2 Kompleksitas Quick Sort}

Algoritma pengurutan Quick Sort memiliki kompleksitas waktu rata-rata dan best case $O(n \log n)$ [16]. Untuk worst case, kompleksitas waktu dari Quick Sort ini adalah $O\left(n^{2}\right)$ yang dimana terjadi apabila data sudah terurut dan pivot yang dipilih adalah data yang pertama [16].

\section{E.2 Merge Sort}

\section{E.2.1 Konsep Merge Sort}

Secara konseptual, sebuah array berukuran n, Merge Sort bekerja sebagai berikut [17] :

1. Jika bernilai 0 atau 1, maka array sudah terurut.

2. Bagi array yang tidak terurut menjadi dua subarray, masing-masing berukuran $\mathrm{n} / 2$.

3. Urutkan setiap sub-array. Jika sub-array tidak cukup kecil, lakukan rekursif langkah 2 terhadap sub-array.

4. Menggabungkan dua sub-array kembali menjadi satu array yang terurut. 


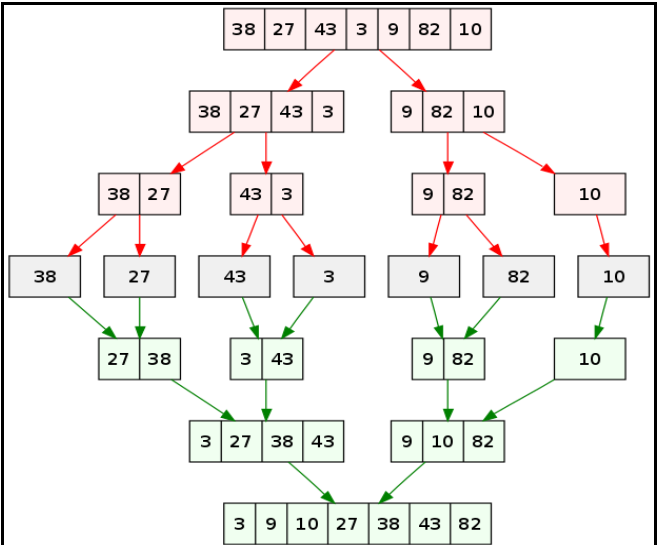

Gambar 4. Contoh simulasi merge sort

\section{E.2.2 Kompleksitas Merge Sort}

Algoritma ini memiliki kompleksitas waktu ratarata, worst case, dan best case yang sama yaitu $O(n$ $\log n)[14]$.

\section{HASIL DAN PEMBAHASAN}

Pada penelitian ini, digunakan beberapa jumlah data yaitu 50, 100, 500, 1.000, 2.500, 5.000, 10.000, $25.000,50.000,100.000$ dengan range 1.000 .000 dan diukur menggunakan besaran millisecond dengan 3 angka dibelakangan koma agar terlihat perbedaannya. Data yang digunakan berlaku untuk semua algoritma sort yang dibahas, dan bahasa pemograman yang digunakan adalah JavaScript. Hasil running time tiap algoritma bergantung pada kondisi dan jenis laptop atau komputer yang digunakan.

\section{A. Bubble Sort}

Gambar 5 merupakan potongan source code JavaScript dari algoritma Bubble Sort:

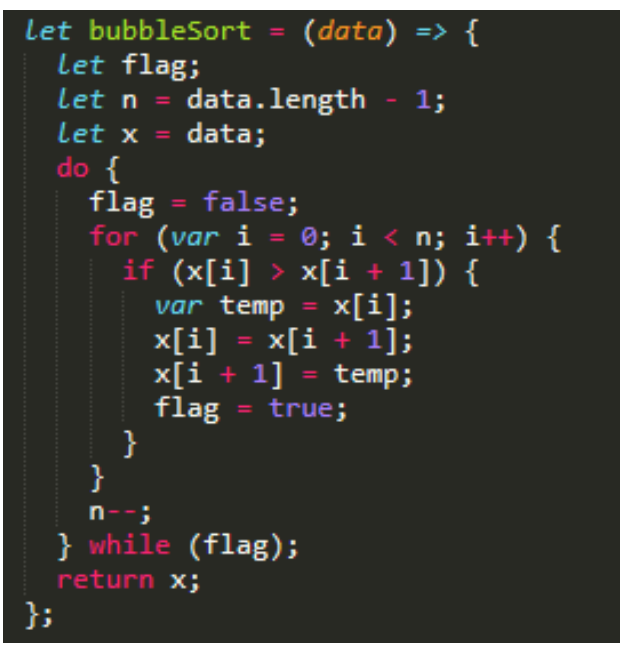

Gambar 5. Potongan source code Bubble Sort
Hasil waktu eksekusi dari algoritma Bubble Sort dapat dilihat pada Tabel 1.

Tabel 1. Waktu eksekusi algoritma Bubble Sort

\begin{tabular}{|c|c|}
\hline Data & Running Time $(\boldsymbol{m s})$ \\
\hline $\mathbf{5 0}$ & 0.24 \\
\hline $\mathbf{1 0 0}$ & 0.425 \\
\hline $\mathbf{5 0 0}$ & 1.98 \\
\hline $\mathbf{1 . 0 0 0}$ & 2.825 \\
\hline $\mathbf{2 . 5 0 0}$ & 9.46 \\
\hline $\mathbf{5 . 0 0 0}$ & 42.4 \\
\hline $\mathbf{1 0 . 0 0 0}$ & 232.175 \\
\hline $\mathbf{2 5 . 0 0 0}$ & 1443.36 \\
\hline $\mathbf{5 0 . 0 0 0}$ & 5330.995 \\
\hline $\mathbf{1 0 0 . 0 0 0}$ & 19379.27 \\
\hline
\end{tabular}

Kompleksitas algoritma Bubble Sort dapat digambarkan seperti grafik berikut.

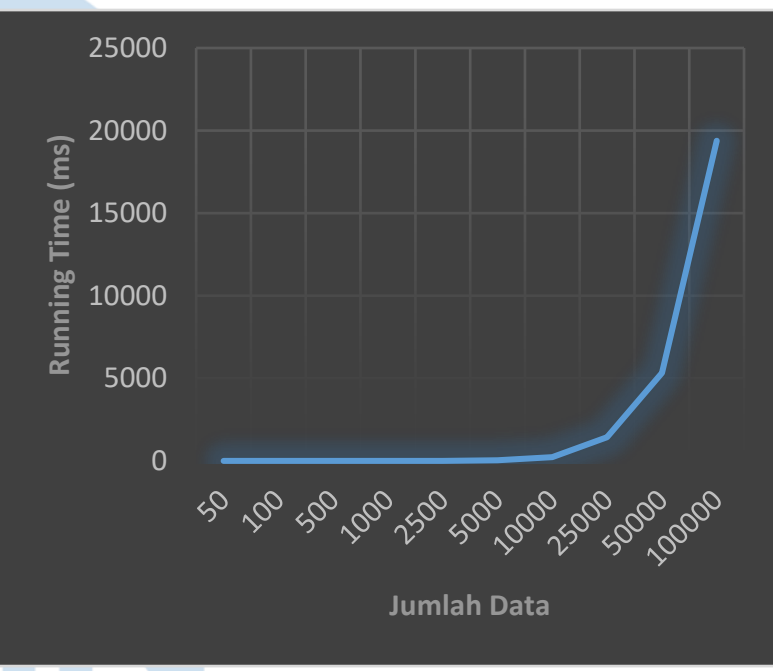

Gambar 6. Grafik kompleksitas algoritma Bubble Sort

\section{B. Selection Sort}

Gambar 7 merupakan potongan source code JavaScript dari algoritma Selection Sort: 


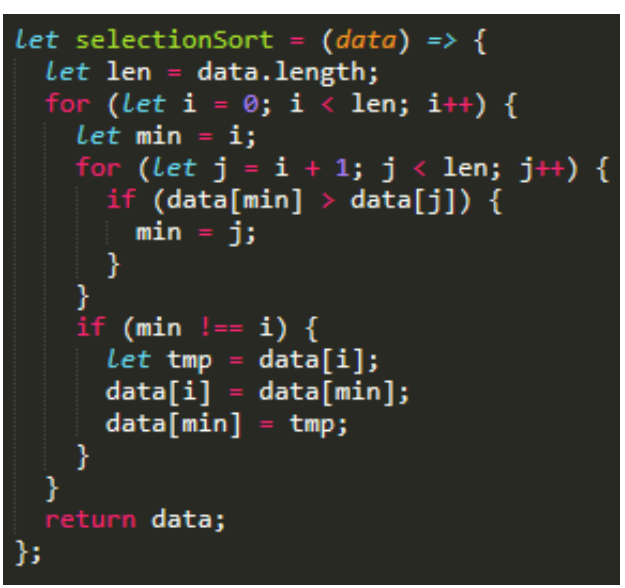

Gambar 7. Potongan source code Selection Sort

Hasil waktu eksekusi dari algoritma Selection Sort dapat dilihat pada Tabel 2.

Tabel 2. Waktu eksekusi algoritma Selection Sort

\begin{tabular}{|c|c|}
\hline Data & Running Time $(\boldsymbol{m s})$ \\
\hline $\mathbf{5 0}$ & 0.105 \\
\hline $\mathbf{1 0 0}$ & 0.23 \\
\hline $\mathbf{5 0 0}$ & 1.36 \\
\hline $\mathbf{1 . 0 0 0}$ & 1.19 \\
\hline $\mathbf{2 . 5 0 0}$ & 2.36 \\
\hline $\mathbf{5 . 0 0 0}$ & 10.025 \\
\hline $\mathbf{1 0 . 0 0 0}$ & 49.48 \\
\hline $\mathbf{2 5 . 0 0 0}$ & 284.925 \\
\hline $\mathbf{5 0 . 0 0 0}$ & 1109.13 \\
\hline $\mathbf{1 0 0 . 0 0 0}$ & 4354.09 \\
\hline
\end{tabular}

Kompleksitas algoritma Selection Sort dapat digambarkan seperti grafik berikut.

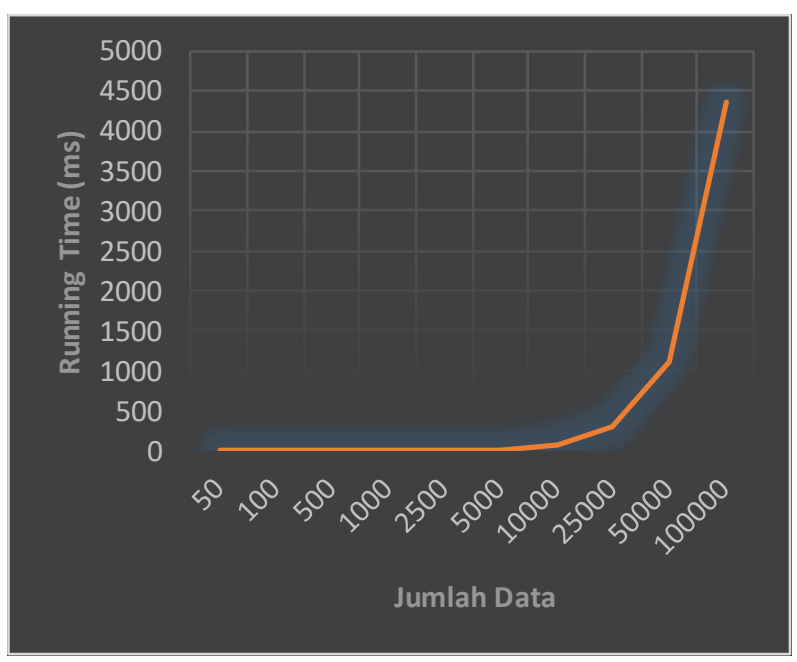

Gambar 5. Grafik kompleksitas algoritma Selection Sort

\section{Quick Sort}

Gambar 9 merupakan potongan source code JavaScript dari algoritma Quick Sort:

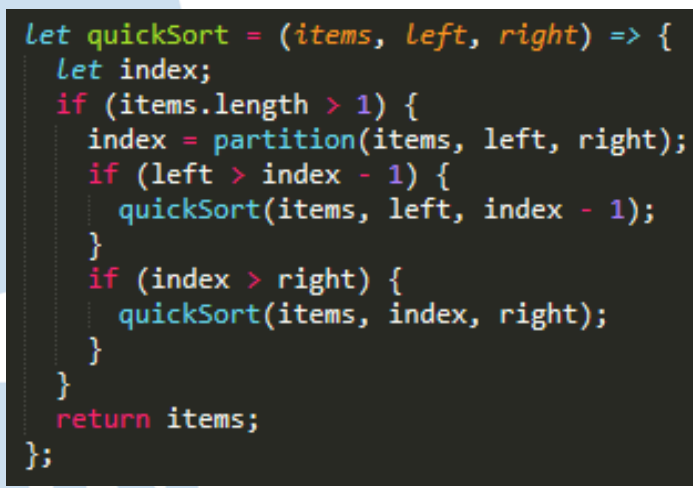

Gambar 9. Potongan source code Quick Sort

Hasil waktu eksekusi dari algoritma Quick Sort dapat dilihat pada Tabel 3.

Tabel 1. Waktu eksekusi algoritma Quick Sort

\begin{tabular}{|c|c|}
\hline Data & Running Time $(\mathbf{m s})$ \\
\hline $\mathbf{5 0}$ & 0.065 \\
\hline $\mathbf{1 0 0}$ & 0.005 \\
\hline $\mathbf{5 0 0}$ & 0.01 \\
\hline $\mathbf{1 . 0 0 0}$ & 0.005 \\
\hline $\mathbf{2 . 5 0 0}$ & 0.005 \\
\hline $\mathbf{5 . 0 0 0}$ & 0.01 \\
\hline $\mathbf{1 0 . 0 0 0}$ & 0.005 \\
\hline $\mathbf{2 5 . 0 0 0}$ & 0.005 \\
\hline $\mathbf{5 0 . 0 0 0}$ & 0.01 \\
\hline $\mathbf{1 0 0 . 0 0 0}$ & 0.015 \\
\hline
\end{tabular}


Kompleksitas algoritma Quick Sort dapat digambarkan seperti grafik berikut.

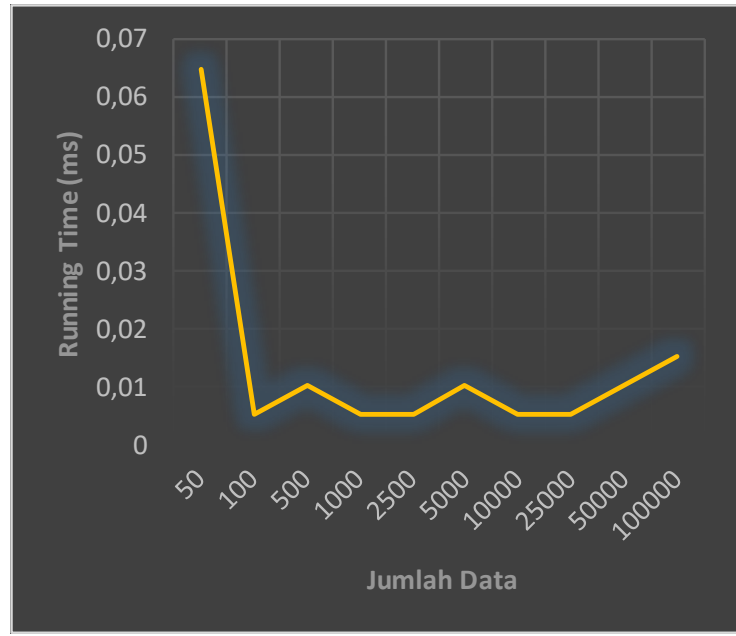

Gambar 10. Grafik kompleksitas algoritma Quick Sort

\section{Merge Sort}

Gambar 11 merupakan potongan source code JavaScript dari algoritma Merge Sort:

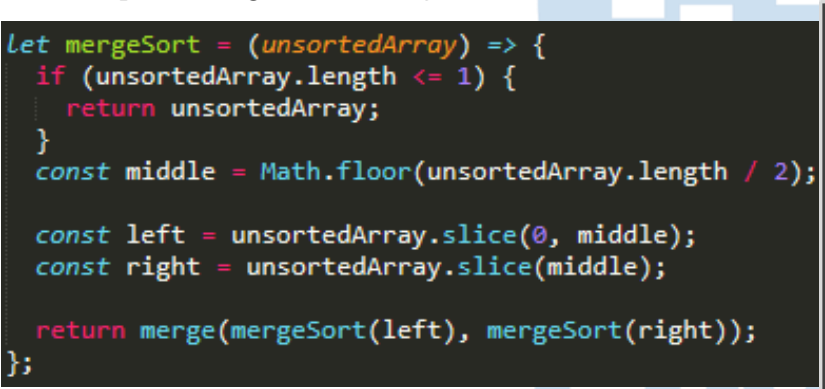

Gambar 11. Potongan source code Quick Sort

Hasil waktu eksekusi dari algoritma Merge Sort dapat dilihat pada Tabel 4.

Tabel 4. Waktu eksekusi algoritma Merge Sort

\begin{tabular}{|c|c|}
\hline Data & Running Time $(\boldsymbol{m s})$ \\
\hline $\mathbf{5 0}$ & 0.15 \\
\hline $\mathbf{1 0 0}$ & 0.18 \\
\hline $\mathbf{5 0 0}$ & 0.81 \\
\hline $\mathbf{1 . 0 0 0}$ & 2.665 \\
\hline $\mathbf{2 . 5 0 0}$ & 6.265 \\
\hline $\mathbf{5 . 0 0 0}$ & 6.3 \\
\hline $\mathbf{1 0 . 0 0 0}$ & 9.18 \\
\hline $\mathbf{2 5 . 0 0 0}$ & 18.815 \\
\hline $\mathbf{5 0 . 0 0 0}$ & 39.265 \\
\hline $\mathbf{1 0 0 . 0 0 0}$ & 78.525 \\
\hline
\end{tabular}

Kompleksitas algoritma Merge Sort dapat digambarkan seperti grafik berikut.

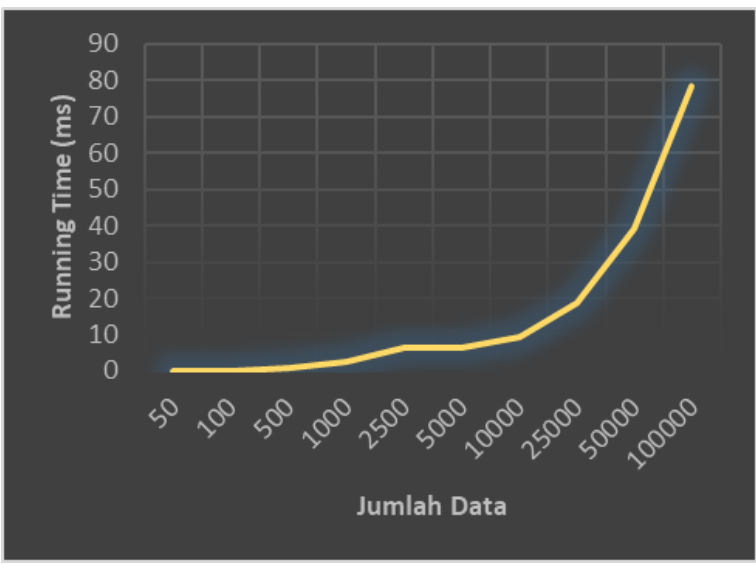

Gambar 12. Grafik kompleksitas algoritma Merge Sort

E. Perbandingan Algoritma Bubble Sort, Selection Sort, Quick Sort dan Merge Sort

Grafik dibawah ini merupakan hasil perbandingan efisiensi strategi Brute Force dan Divide and Conquer.

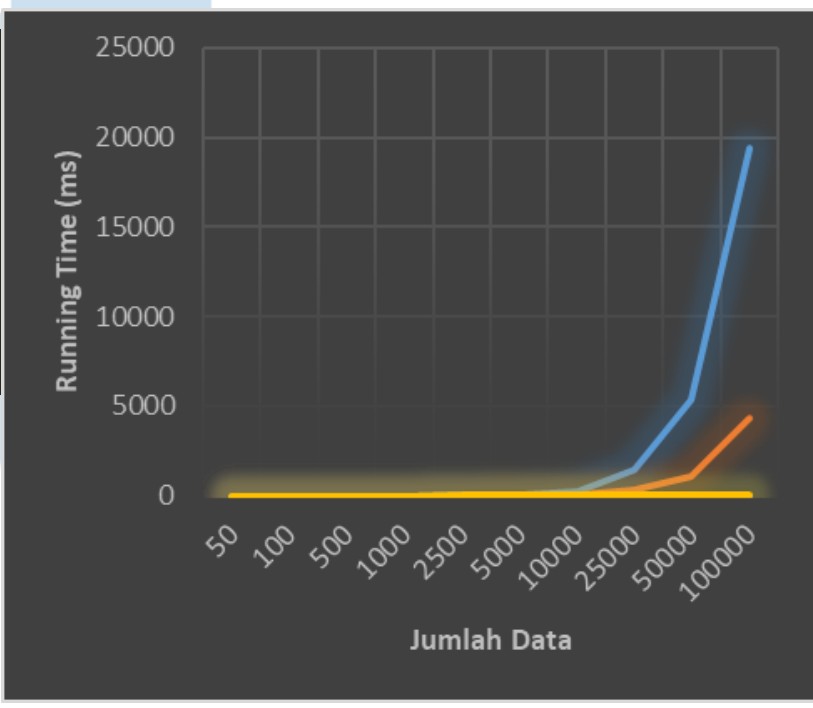

Gambar 13. Grafik perbandingan kompleksitas algoritma

\section{SIMPULAN}

Berdasarkan dari hasil algoritma pengurutan yang dilakukan menggunakan strategi Brute Force dan Divide and Conquer, dapat disimpulkan bahwa strategi Divide and Conquer lebih efektif dan efisien dalam menangani masalah pengurutan. Algoritma yang mudah dalam hal implementasi adalah Bubble Sort dan Selection Sort, keduanya memiliki kompleksitas $O\left(n^{2}\right)$. Algoritma yang lebih efisien adalah algoritma Quick Sort dan Merge Sort dengan 
kompleksitasnya adalah $O(n \log n)$. Dari keempat algoritma ini, yang memiliki efisiensi paling bagus adalah algoritma Quick Sort dengan running time rata-rata sebesar $0,0135 \mathrm{~ms}$ dari data yang diuji. Sedangkan bubble sort merupakan algoritma yang memiliki efisiensi paling buruk dari keempat algoritma yang diuji dengan running time rata-rata sebesar 2644,313 ms dari data yang diuji.

\section{DAFTAR PUSTAKA}

[1] "Sorting Algorithms," [Online]. Available: https://guide.freecodecamp.org/algorithms/sortingalgorithms/. [Accessed 20 Mei 2020].

[2] Amran. "Perbandingan Strategi Brute Force dan Divide and Conquer Pada Algoritma Pengurutan". https://www.academia.edu/39080158/Perbandingan_Strategi_ Brute_Force_and_Divide_an_Conquer_Pada_Algoritma_Pen gurutan. [Accessed 20 Mei 2020]

[3] Wikipedia, http://en.wikipedia.org/wiki/ Big_O_notation/ ". [Accessed 20 Mei 2020].

[4] "Best, Worst, and Average-Case Complexity," [Online]. Available: https://www8.cs.umu.se/kurser/TDBA77/VT06/algorithms/B OOK/BOOK/NODE13.HTM. [Accessed 22 Mei 2020].

[5] "Algorithm Efficiency," [Online]. Available: http://www.cs.kent.edu/ durand/CS2/Notes/03_Algs/ds_alg_ efficiency.html. [Accessed 22 Mei 2020].

[6] "Time Complexity," [Online]. Available: https://www.techopedia.com/definition/22573/timecomplexity. [Accessed 22 Mei 2020].
[7] D. W. Nugraha, "Penerapan Kompleksitas Waktu Algoritma Prim Untuk Menghitung Kemampuan Komputer Dalam Melaksanakan Perintah," vol. 2, 2012.

[8] A. H. Estrada S, "Telaah Waktu Eksekusi Program Terhadap Kompleksitas Waktu Algoritma Brute Force Dan Divide And Conquer Dalam Penyelesaian Operasi List," vol. 3, 2003.

[9] S. N. B. Tjaru, "Kompleksitas Algoritma Pengurutan Selection Sort dan Insertion Sort". MAKALAH IF2091 STRATEGI ALGORITMIK, 2009.

[10] P. Triono, "Analisis Perbandingan Algoritma Sorting dan Searching". https://www.academia.edu/6526802/Analisisperbandingan-algoritma, 2010. [Accessed 22 Mei 2020].

[11] S. Y. Yahya, "Analisa Perbandingan Algoritma Bubble Sort dan Selection Sort Dengan Metode Perbandingan Eksponensial," Pelita Informatika Budi Darma, vol. VI, 2014.

[12] K. Ali, "A Comparative Study of Well Known Sorting Algorithms," International Journal of Advanced Research in Computer Science, vol. 8, no. 1, pp. 277-280, 2017.

[13] M. Usman, M. Afzal and Z. Bajwa, "Performance Analysis of Sorting Algorithms with C\#," International Journal for Research in Applied Science \& Engineering, vol. 3, no. 1, pp. 201-204, 2015.

[14] D. Rajagopal and K. Thilakavalli, "Different Sorting Algorithm's Comparison based Upon the," International Journal of $u$ - and e-Service, Science and Technology, vol. 9, no. 8, pp. 287-296, 2016.

[15] N. D. S. L. S. P. Parag Bhalchandra, "A Comprehensive Note on Complexity Issues in Sorting Algorithms," Advances in Computational Research, vol. 1, no. 2, pp. 1-9, 2009.

[16] M. E. Wira Putra, "Perbandingan Algoritma Pengurutan Merge Sort, Quick Sort dan Heap Sort Dilihat dari Kompleksitasnya".https://informatika.stei.itb.ac.id/ rinaldi.m unir/Matdis/2009-2010/Makalah0910/MakalahStrukdis0910023.pdf [Accessed 22 Mei 2020]. 